\title{
Students' Ability at Changing Direct into Indirect Speech and Indirect into Direct Speech
}

\author{
Muhammad Dalimunte ${ }^{1}$, Maryati Salmiah ${ }^{1}$

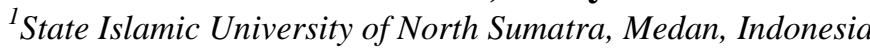 \\ muhammaddalimunte@uinsu.ac.id
}

\begin{abstract}
Abstarct : Reported speech is one of difficult topics in learning English grammar, especially in changing the form from direct into indirect or reverse. Descriptive quantitative was used to find out the students' ability in changing direct into indirect speech and reverse. There were five sentences that were changed by the students for two kinds of test. First, the test consisted of five direct sentences and the second, it consisted five indirect sentences. As the conclusion of the students' answers, the students found difficulties in changing those two kinds of sentences.
\end{abstract}

Keywords : Students’Ability; Direct Speech; Indirect Speech

\section{Introduction}

English as an international language has an important role in many aspects of life. This is one of the reasons why English is learnt by many people in the world. Mastering English well, then we'll be able to communicate with other nations in the world. Besides, we can also add insight and knowledge to the progress of our nation and country, because we'll be able to read English literature, listen to foreign radio broadcasts, and watch foreign films that can add our knowledge. Thus, ultimately we can master the knowledge in all fields.

Every language of course has rules or we often refer to the term of each grammar. As well as with English, a lot of rules that must be considered in its use, especially in the field of writing and structure. Therefore, we try to present one of the grammars of the many grammars of English. That is Reported speech.

Reported Speech is a structure used to report what somebody said. It implies, in most of cases, changing the verb tense of the original sentence and sometimes the place and time stated. If we report what another person has said, we usually don't use the speaker's exact words (direct speech), but reported (indirect speech). Therefore, we need to learn how to transform direct speech into reported speech. The structure is a little different depending on whether you want to transform a statement, question or request.

Reported speech is commonly used to report what other people have said or though without reporting the exact word. With reported speech, one wishes to report the content of the original source without necessarily repeating sentences exactly as they were originally uttered.

By learning reported speech definitely we will able to quote somebody's words or thoughts whether in direct or indirect speech and also we will learn and understand the way to report speech.

If we report what another person has said, we usually don't use the speaker's exact words (direct speech), but reported (indirect speech). Therefore, we need to learn how to transform direct speech into reported speech. The structure is a little different depending on whether you want to transform a statement, question or request.

In English grammar, reported speech is important to be learnt by students because it is one of three ways for students to report or share their statements to other people. In this paper, the write wanted to prove that students found difficulties in learning this topic. This 
topic is learnt by second semester students of English Educational Department on Tarbiyah Science and Teacher Training Faculty in State Islamic University of Medan.

\section{Review of Litearature}

According to J.K. Gangal in Competitive English for Professional Courses (New Delhi: S.Chand \& Company Ltd, 2008) there are two ways to report what someone has said;

a) Direct Speech

When we use the exact words of the speaker to report we call it Direct Speech, and the exact words of the speaker are put within inverted commas or quotation marks.

b) Indirect Speech

Another way to report people's words and thoughts is to us our own words. When we do so we use sentences that have a reporting clause and a reported clause.

According to Jayanthi Dakhsina Murthy in Contemporary English Grammar (Delhi: Book Palace, 2015) There are main point to remember:

a) Direct speech should be placed between the inverted commaand begin with a capital letter.

Example: Padma said, "I want to study medicine".

b) No inverted commas and comma are used in direct speech.

Example: Padma said that she wanted to study medicine.

c) A conjuction is used after the reporting speech in indirect speech.

Example: She told me that she would marry me.

d) Tense/pronoun/word indicating nearness of time and position are changed.

Example: Madhavi said to me, "I waited for you here today".

Madhavi told me that she waited for me there that day

\subsection{Rule For Tense Change}

There are some changes based on the tenses, here are the formula:

\begin{tabular}{|c|c|}
\hline Direct speech & Indirect speech \\
\hline Simple present & Simple past \\
\hline Present continious & Past continious \\
\hline Present perfect & Past perfect \\
\hline Present perfect continious & Past perfect continious \\
\hline Simple past & Past perfect \\
\hline Past perfect & No change \\
\hline Past perfect continious & No change \\
\hline Simple future & Future conditional \\
\hline May & Might \\
\hline Can & Could \\
\hline Oughtto & - \\
\hline
\end{tabular}


The using of the above formula can be seen as the following example:

Direct Speech: $\quad$ Uma said, "I like teaching."

Indirect Speech: $\quad$ Uma said that she liked teaching.

\subsection{Pronoun in Indirect Speech}

In spite of the tense, to change the direct speech into indirect speech or reverse, the pronoun also needs to change, here are the forms:

Example

\begin{tabular}{|c|c|c|c|}
\hline \multirow{2}{*}{$\begin{array}{l}\text { E } \\
x \text { Direct speech } \\
a\end{array}$} & \multicolumn{3}{|c|}{ Indirect speech } \\
\hline & Masculine & Feminime & Plural \\
\hline \begin{tabular}{|ll}
$\mathrm{m}$ & $\mathrm{I}$ \\
$\mathrm{p}$ & \\
\end{tabular} & $\mathrm{He}$ & She & They \\
\hline You & $\mathrm{He}$ & She & They \\
\hline You & Him & Her & Them \\
\hline Your & His & Her & Their \\
\hline $\mathrm{Me}$ & Him & Her & Them \\
\hline My & His & Her & Their \\
\hline Myself & Himself & Herself & Themselves \\
\hline We & & & They \\
\hline Us & & & Them \\
\hline Our & & & Their \\
\hline
\end{tabular}

To use the change of the pronouns are below:

Direct Speech: I had lost my hand bag" said Ramya

Indirect Speech: Ramya said that she had lost her hand bag

\subsection{Words Denoting Time And Position}

Besides tenses and pronoun, to change the direct into indirect speech or reverse, the words refer to time and position also need to change. The following are the forms:

\begin{tabular}{|c|c|}
\hline Direct Speech & Indirect Speech \\
\hline This & That \\
\hline These & Those \\
\hline Now & Than \\
\hline Ago & Before \\
\hline Last night & The previous night \\
\hline Next day & The following day \\
\hline
\end{tabular}




\begin{tabular}{|c|c|}
\hline Today & That day \\
\hline Tomorrow & The following day \\
\hline Just & Than \\
\hline
\end{tabular}

To use the forms, here are the examples:

Direct Speech: "where do you want to go now?"

Indirect Speech: He asked me where I wanted to go then.

a) In reported speech we usually report what was said at a different time, and so we change the tense to reflect the time which we are reporting. We normally "shift back" one tense.

Direct speech: "I'm not playing football."

Reported later: "He said that he wasn't playing football."

b) Sometimes the pronoun needs to be changed.

Direct speech: Jane: "I don't like living here." (Jane is referring to herself)

Reported speech: Jane said (that) she didn't like living here. (The pronoun she refers to Jane)

c) Other words about place and time may also need to be changed.

Direct speech: "I like this car."

Reported speech: He said (that) he liked that car.

Direct speech: "I went to Tokyo last week."

Reported speech: She said (that) she'd been to Tokyo the week before.

\subsection{Meaning}

We use reported speech to tell someone what another person said:

Jim says to you: "I don't feel well."

Later, you tell your friend what Jim said:

Jim said (that) he didn't feel well.

\subsection{Additional points}

There are some adding points in changing reported speech:

a) If you report something which is still true, it is not necessary to change the verb.

Direct speech: "My car is bigger than yours."

Reported speech: He said his car is/was bigger than mine.

b) When we are reporting past tenses and we see the events from the same viewpoint as the original speaker, it is not necessary to change the tense.

Direct speech: "The earthquake happened at half past seven."

Reported speech: The radio said that the earthquake happened at half past seven.

c) Modal verbs could, might, would, should, ought, had better usually do not change in reported speech.

Direct speech: "I should go to the dentist."

Reported speech: He said that he should go to the dentist.

\begin{tabular}{|l|l|}
\hline \multicolumn{1}{|c|}{ Direct Speech } & \multicolumn{1}{c|}{ Indirect Speech } \\
\hline $\begin{array}{l}\text { Simple Present } \\
\text { ("I never eat meat", he explained) }\end{array}$ & $\begin{array}{l}\text { Simple Past } \\
\text { (=he explained that he never ate meat) }\end{array}$ \\
\hline $\begin{array}{l}\text { Present Continuous } \\
\text { ("I'm waiting for Ann", he said) }\end{array}$ & $\begin{array}{l}\text { Past Continuous } \\
\text { (=He said that he was waiting for Ann) }\end{array}$ \\
\hline
\end{tabular}




\begin{tabular}{|l|l|}
\hline $\begin{array}{l}\text { Present Perfect } \\
\text { ("I have found a flat", he said) }\end{array}$ & $\begin{array}{l}\text { Past Perfect } \\
\text { (=He said that he had found a flat) }\end{array}$ \\
\hline $\begin{array}{l}\text { Present Perfect Continuous } \\
\text { (He said, "I've been waiting for ages".) }\end{array}$ & $\begin{array}{l}\text { Past Perfect Continuous } \\
\text { (=He said that he had been waiting for } \\
\text { ages) }\end{array}$ \\
\hline $\begin{array}{l}\text { Simple Past } \\
\text { ("I took it home with me", she said) }\end{array}$ & $\begin{array}{l}\text { Past Perfect } \\
\text { (=She said that he had taken it home } \\
\text { with her) }\end{array}$ \\
\hline $\begin{array}{l}\text { Future } \\
\text { (He said, "I will/shall be in Paris on } \\
\text { Monday".) }\end{array}$ & $\begin{array}{l}\text { Conditional } \\
\text { (=He said that he would be in Paris on } \\
\text { Monday) }\end{array}$ \\
\hline $\begin{array}{l}\text { Future Continuous } \\
\text { ("I will/shall be using the car myself on } \\
\text { the 24th".) }\end{array}$ & $\begin{array}{l}\text { Conditional Continuous } \\
\text { (=She said that she'd been using the car } \\
\text { herself on the 24 } 4^{\text {th }} \text {.) }\end{array}$ \\
\hline $\begin{array}{l}\text { Conditional } \\
\text { (I said, "I would like to see it".) }\end{array}$ & $\begin{array}{l}\text { Conditional } \\
\text { (=I said that I would like to see it.) }\end{array}$ \\
\hline
\end{tabular}

\section{Research Method}

In here, test was used as an instrument to obtain the data. A written test was given that focused on the subject matter that would be studied. The test consisted of 10 questions. It was divided into two parts. The first part consisted of five questions that asking the students about how to change the direct sentence into indirect sentence. In the second part consisted of five questions that asking the students about to change the indirect sentence into direct sentence.

The written test was given to get the frequency of error in answering the test in order to know the average of student problem or difficulties in learning Reported Speech. After that, the technique of data analysis was used descriptive analysis technique (percentage) with the formula:

$$
\begin{aligned}
& \mathbf{P}=\mathbf{F} / \mathbf{N} \mathbf{X} \mathbf{1 0 0 \%} \\
& \mathrm{P}=\text { Percentage } \\
& \mathrm{F}=\text { Frequency of wrong answer } \\
& \mathrm{N}=\text { Number of sample which observed }
\end{aligned}
$$

After having the frequency and percentage of difficulty, the writer then looked for the average mark by using formula:

$$
\mathrm{P}=\mathrm{F} / \mathrm{NXn} \mathrm{X} 100 \%
$$

$\mathrm{P}=$ Percentage

$\mathrm{F}=$ Frequency of wrong answer

$\mathrm{N}=$ Number of sample

$\mathrm{n}=$ Number of item test

Besides the percentage, interview was applied to some students who got bad and who got the good scores in the test that written before.

\section{Research Finding and Discussion}

After the test had done, collecting data was needed and counted the correct answer and also the wrong answers from each sheet of the collected test. The data were taken from some 
classes that are the English Educational Department students which consisted of 50 students. In this below, it was provided a table which is the answers of each question that has been answered by the sample. In this section, the description of the data was described. These were two parts of test that given to take student's score in reported speech question:

1. Part A: To test student's ability to change the indirect questions into the direct questions.

2. Part B: To test student's ability to change the direct questions into the indirect questions.

After analyzing the answers, then those were counted the correct and wrong answers from the students. There was 50 students answer the questions. The table below was showed the data.

Table 1. Students' Correct Answers

\begin{tabular}{|c|c|c|}
\hline No & Score & Total Number of the Students \\
\hline 1 & $0-9$ & 12 Students \\
\hline 2 & $10-19$ & 2 Students \\
\hline 3 & $20-29$ & 5 Students \\
\hline 4 & $30-39$ & 4 Students \\
\hline 5 & $40-49$ & 4 Students \\
\hline 6 & $50-59$ & 5 Students \\
\hline 7 & $60-69$ & 7 Students \\
\hline 8 & $70-79$ & 2 Students \\
\hline 9 & $80-89$ & 3 Students \\
\hline 10 & $90-99$ & 4 Students \\
\hline 11 & 100 & 2 Students \\
\hline \multicolumn{2}{|c|}{ Total } & 50 Students \\
\hline
\end{tabular}

From the table 1 above, it showed that the students were 50 students, and there were 11 score categories from the result of the test. There were from 0 until 100 scores. The highest score is 100 gotten by 2 students, while the lowest score is $0-9$ which was gotten by 12 students. From the test result above, it was concluded that the students had low ability in mastering the Reported Speech topic.

After collecting the tests' result, the first step, it was collected the questions which answered by the samples. Then, students' difficulties in answering reported speech questions were analyzed. The analyzing of the students' answering questions was showed in table 2.

Table 2. Analyzing of the Students' Answering Questions

\begin{tabular}{|c|l|c|}
\hline A & \multicolumn{1}{|c|}{ Change into Direct Speech } \\
\hline \multicolumn{1}{|c|}{ Questions } & Number of Students \\
\hline 1 & $\begin{array}{l}\text { Ramya said that she had lost her hand } \\
\text { bag. }\end{array}$ & 3 \\
\hline 2 & $\begin{array}{l}\text { Devi told me that she could do anything } \\
\text { for me. }\end{array}$ & 3 \\
\hline 3 & $\begin{array}{l}\text { Murty told madhavi that he used to } \\
\text { write stories. }\end{array}$ & 3 \\
\hline 4 & Uma said that she liked teaching. & 12 \\
\hline 5 & Dara told me that she had posted the & 4 \\
\hline
\end{tabular}




\begin{tabular}{|c|l|c|}
\hline & letter. & Change into Indirect Speech \\
\hline B & \multicolumn{1}{|c|}{ Questions } & Number of Students \\
\hline \multicolumn{1}{|c|}{} \\
\hline 1 & $\begin{array}{l}\text { Prasad said, " I had been thinking of } \\
\text { marrying a rich girl. }\end{array}$ & 5 \\
\hline 2 & "You may go now", I said to sailaja. & 4 \\
\hline 3 & $\begin{array}{l}\text { My father said,"honesty is the best } \\
\text { policy" }\end{array}$ & 5 \\
\hline 4 & $\begin{array}{l}\text { "You had better consult a good doctor", } \\
\text { ramanji said to me. }\end{array}$ & 4 \\
\hline 5 & Mayda said to me, "I loved you". & 7 \\
\hline \multicolumn{2}{|c|}{ Total } & $\mathbf{5 0}$ \\
\hline
\end{tabular}

The table 2 showed that there were 10 questions that answered by 50 students. The answered of the students was divided into two, 25 students for changing indirect into direct and the others changing indirect into direct. In the results of the test that had been done, it got the result that: Part A question number 1 was answered by 3 students, number 2 was answered by 3 students, question number 3 was answered by 3 students, number 4 was answered by 12 students, number 5 was answered by 4 students.

Part B, number 1 was answered by 5 students, number 2 was answered by 4 students, number 3 was answered by 5 students, number 4 was answered by 4 students, and number 5 was answered by 7 students.

From the description above, it was concluded that many students could not answer the question of number a1, a2 and a3. And most of them could answer the question number 4a.

In this case, it was found that the students could not change direct into reported speech and some of students able to change indirect into direct speech and they found difficulties in changing the pronouns and also understanding the questions.

To find out the reason why the students got difficulties in learning reported speech topic, interview was done. Two students were interviewed that was consisted of 1 student who got the highest score and the other who got the lowest score. In doing the interview, it was proposed a question that related to the topic that must be answered honestly by the student.

We found that many students did not understand yet about reported speech. They did not master about the rules for sequence of changing the tenses and pronoun in reported speech. They confused to change the time from original question into the time which was reported and to change the speaker one turned into speaker $3^{\text {rd }}$ person. They had a worse opinion that grammar was difficult. The other reason, the test started in the class in the short time to think and finish the test. Besides, according to them, the questions were very difficult to answer but they said they had done the best in answering the questions.

\section{Conclusions}

The students made many mistakes in transfering form from direct speech to indirect speech and on the contrary, they also got difficulty to change the tenses, pronoun and the time signal in sentences. They need to practice more both in spoken and written language. 
One of the way to increase their ability is to give them more exercise in teaching -learning process in the classroom and also drive them to practice out of the class.

\section{References}

Murthi, Jayanthi Dakshina. Contemporary English Grammar: Reference and Practice Through Real English. Delhi: Book Palace

Farbman, Evelyn. 1985. Signals: A Grammar and Guide for Writers. Boston: Houghton Mifflin Company

Drummond, Gordon. 1972. English Structure Practice. England: Longman Group Limited

Gangal, J.K. 2008. Competitive English: For Professional Courses. New Delhi: S.Chand \& Company Ltd.

Librata, Greta C. ,dkk. 1980. Bahasa Inggris: Untuk Fakultas Ilmu-Ilmu Sosial. Jakarta: Bhratara Karya Aksara

Bergler, Sabine. 1955. Conveying Attitude with Reported Speech. Canada: Department of Computer Science and Computer Engineering 